\title{
FAKTOR-FAKTOR PENGHAMBAT PELAKSANAAN PROGRAM AIR SUSU IBU (ASI) EKSKLUSIF DI KELURAHAN TULADENGGI KECAMATAN DUNGINGI KOTA GORONTALO
}

\author{
Sarja Ikano \& Nolfi S. Tueno \\ STIA Bina Taruna Gorontalo \\ bukujurnalstia@binataruna.ac.id $\& \underline{\text { nolfitueno@gmail.com }}{ }^{2}$
}

\begin{abstract}
ABSTRAK
Penelitian ini bertujuan untuk mengetahui faktor-faktor penghambat pelaksanaan program Air Susu Ibu (ASI) Eksklusif di Kelurahan Tuladenggi Kecamatan Dungingi Kota Gorontalo. Metode penelitian menggunakan jenis deskriptif pendekatan kualitatif. Teknik pengumpulan data dilakukan melalui wawancara mendalam kepada sejumlah informan, observasi dan pencatatan data sekunder yang berkaitan dengan permasalahan penelitian.

Hasil penelitian menyimpulkan bahwa, sosialisasi yang dilakukan oleh para petugas belum optimal. Hal ini terlihat dari bentuk sosialisasi yang hanya tersentral pada satu tempat saja. Pengetahuan masyarakat akan penggunaan dan manfaat Air Susu Ibu (ASI) Eksklusif masih rendah. Hal ini terlihat dari pengetahuan para ibu yang kurang tentang teknik dan tata cara menggunakan Air Susu Ibu (ASI) Eksklusif khususnya untuk Air Susu Ibu (ASI). Pendampingan pelaksanaan program Asi Eksklusif di Kelurahan Tuladenggi belum optimal. Hal ini dikarenakan keterbatasan jumlah kader yang tidak sebanding dengan luasnya wilayah kerja para kader. Selain itu para kader kurang menguasai proses laktasi baik secara teknis maupun secara teoritis.

Disarankan, perlunya dilakukan kegiatan sosialisasi yang lebih komprehensip dengan melakukan kunjungan langsung kerumah-rumah warga. Perlunya meningkatkan pengetahuan para ibu dengan memberikan kelas khusus tentang pentingnya penggunaan Air Susu Ibu (ASI) Eksklusif. Perlunya dilakukan pendampingan dengan memberikan pembekalan wawasan dan teknik laktasi kepada para kader
\end{abstract}

Kata Kunci: Pelaksanaan Program Air Susu Ibu (ASI) Eksklusif

\section{PENDAHULUAN}

Di Indonesia cakupan Air Susu Ibu (ASI) Eksklusif masih jauh dari harapan. Target pemerintah Indonesia yang menetapkan sekurangnya $80 \%$ pencapaian ASI Eksklusif melalui Surat Keputusan Menteri Kesehatan sejak tahun 2004 Nomor 450/Menkes/SK/IV/2004 dan UndangUndang Kesehatan Nomor 36 Tahun 2009 Pasal 128 ayat (1) menyebutkan bahwa setiap bayi berhak mendapatkan ASI Eksklusif sejak lahir sampai enam bulan kecuali atas indikasi medis belum tercapai. ASI Eksklusif menurut 
World Health Organization (WHO, 2011) adalah memberikan hanya ASI saja tanpa memberikan makanan dan minuman lain kepada bayi sejak lahir sampai usia 6 bulan kecuali obat dan vitamin.

Dalam pembangunan bangsa, peningkatan kualitas manusia harus dimulai sedini mungkin yaitu sejak masih bayi. Salah satu faktor yang memegang peranan penting dalam peningkatan kualitas manusia adalah pemberian ASI. Pemberian ASI Eksklusif merupakan kegiatan penting dalam mempersiapkan generasi penerus bangsa yang cerdas dan sehat. Terjadinya kerawanan gizi pada bayi disebabkan tidak terpenuhinya zat gizi penting yang menjadi sumber protein, vitamin, dan mineral. Setiap tetes ASI Eksklusif mengandung enzim untuk pencegahan penyakit dan antibody yang lebih efektif dibandingkan dengan kandungan yang terdapat dalam susu formula. Selama pematangan system kekebalan sedang berlangsung ASI Eksklusif mengandung Immunoglobulin A $(\lg \mathrm{A})$ yang kadarnya tinggi dan mampu melindungi bayi terhadap serangan bakteri dan virus terutama di saluran napas dan saluran cerna (Wong, 2009).

Penyebab utama kematian bayi balita adalah diare dan pneumonia dan lebih dari $50 \%$ kematian bayi balita masih didasari oleh kurang gizi. Pemberian ASI Eksklusif selama 6 bulan dan diteruskan sampai usia 2 tahun disamping pemberian makanan pendamping terbukti merupakan salah satu intervensi efektif dalam penurunan Angka Kematian Bayi
(AKB). Sedangkan salah satu tujuan Millenium Development Goals (MDGs) adalah peningkatan kesehatan ibu dengan target menurunkan angka kematian bayi. ASI Eksklusif berperan dalam system pertahanan tubuh bayi untuk mencegah berbagai penyakit.

Dengan menyusui dapat menurunkan resiko pendarahan saat persalinan, kanker payudara, kanker ovarium, dan kanker endometrosis, mempercepat pemulihan kesehatan ibu pasca melahirkan. Selain itu, dengan pemberian ASI Eksklusif dapat menjadi alat kontrasepsi yang baik dan dapat menurunkan resiko kehamilan. Pemberian ASI Eksklusif tidak sekedar rekomendasi World Health Organization (WHO) tetapi dianjurkan agama sebagai makanan bayi ciptaan Allah SWT yang tidak dapat digantikan dengan makanan dan minuman lain, sebagaimana yang tercantum dalam Al-Qur'an dalam surah Al-Baqarah; 233, yaitu ibu-ibu hendaklah menyusui anak-anaknya selama dua tahun penuh, bagi yang ingin menyusui secara sempurna. Kewajiban ayah menanggung nafkah dan pakaian mereka dengan cara yang patut (ma'ruf).

Dalam upaya mencerdaskan kehidupan bangsa, maka harus dilahirkan generasi penerus bangsa yang cerdas, sehat jasmani dan rohani. Untuk itu perlu penciptaan kondiisi yang mendukung kearah tersebut, diantaranya dengan pemberian ASI secara eksklusif selama 6 bulan yang dilanjutkan sampai berusia 2 tahun sehingga pengeluaran keluarga lebih terkendali karena tidak perlu membeli 
susu formula dan bisa di alokasikan pada kebutuhan lain yang lebih penting.

Keberhasilan pemberian ASI eksklusif memerlukan dukungan dan pengawasan dari berbagai pihak yang terdiri dari keluarga khususnya ayah, pemerintah, tenaga kesehatan, kader posyandu yang ada di masyarakat. Posyandu dan kader merupakan ujung tombak pelayanan kesehatan dalam peningkatan pemberian ASI eksklusif serta pemantauan tumbuh kembang bayi balita. Kader kesehatan yang ada di posyandu diharapkan dapat menyelesaikan masalah-masalah umum yang terjadi di masyarakat dengan meningkatkan pengawasan terhadap permasalahan tersebut. Namun demikian dalam pelaksanaannya, program ASI eksklusif ditengah-tengah masyarakat belum optimal. Demikian halnya dengan pelaksanaan program ASI eksklusif di Kelurahan Tuladenggi Kecamatan Dungingi Kota Gorontalo dianggap belum optimal sejak dilaksanakannya pada tahun 2014

Berdasarkan obervasi awal penulis, menunjukkan bahwa belum optimalnya pelaksanaan program ASI eksklusif di Kelurahan Tuladenggi Kecamatan Dungingi Kota Gorontalo disebabkan oleh beberapa faktor di antaranya;

Kurangnya kegiatan sosialisasi atau penyuluhan yang dilakukan oleh petugas Puskesmas tentang cara-cara yang tepat dalam menyusui dan manfaat dari program ASI eksklusif. Sosialisasi program ASI eksklusif kalah bersaing dengan kegiatan promosi susu formula yang ada di media elektronik maupun pada media cetak. Selama ini sosialisasi tentang program ASI eksklusif lebih banyak dilakukan di pusat-pusat penyelenggaraan kesehatan seperti rumah sakit (rumah bersalin) dan puskesmas dan belum secara langsung ke tempat tinggal dimana masyarakat berada.

Rendahnya pengetahuan para orang tua (ibu) akan pentingnya pemberian ASI eksklusif, zat-zat penting yang terkandung dalam ASI eksklusif. Selain itu, para orang tua (ibu) juga kurang memiliki edukasi tentang cara-cara menyusui yang baik dan benar sehingga banyak dari para orang tua (ibu) merasa terbebani jika harus menyusui anaknya melalui ASI eksklusif dan lebih memilih susu formula karena dianggap lebih praktis. Adapun jumlah orang tua (ibu) yang saat ini menyusui sekitar 60 orang (data; November 2018).

Kurangnya kegiatan pendampingan dari para kader bagi ibu-ibu peserta program ASI eksklusif sehingga masyarakat atau para orang tua kurang memiliki kesadaran akan pentingnya program ASI eksklusif. Jumlah kader yang hanya 10 orang juga menjadi salah satu alasan dari kurang optimalnya kegiatan pendampingan di Kelurahan Tuladenggi Kecamatan Dungingi yang memiliki jumlah penduduk yang cukup padat. 


\section{PERMASALAHAN}

Berdasarkan uraian masalah dan identifikasi masalah di atas, maka rumusan masalah penelitian ini adalah: Faktor-faktor apa saja yang menghambat pelaksanaan program ASI Eksklusif di Kelurahan Tuladenggi Kecamatan Dungingi Kota Gorontalo?

\section{TUJUAN DAN MANFAAT PENELITIAN}

Adapun tujuan dalam penelitian ini adalah untuk mengetahui faktorfaktor yang menghambat pelaksanaan program ASI eksklusif di Kelurahan Tuladenggi Kecamatan Dungingi Kota Gorontalo.

\section{Manfaat Penelitian}

Secara teoritis; dapat memberikan, menambah khasanah ilmu pengetahuan khsusunya ilmu adminstrasi dan dapat dijadikan acuan ataupun rujukan untuk penelitian sejenis atau penelitian lanjutan.

Secara praktis; diharapkan penelitian ini dapat dijadikan sebagai bahan evaluasi terhadap pelaksanaan program ASI eksklusif di Kelurahan Tuladenggi Kecamatan Dungingi Kota Gorontalo.

\section{METODE PENELITIAN}

Penelitian ini menggunakan jenis penelitian deskriptif dengan pendekatan kualitatif. Penelitian deskriptif oleh Mochtar (2008:76) dalam bukunya Metodologi Penelitian
Kualitatif adalah menggambarkan berbagai fenomena informasi yang berkaitan dengan fokus penelitian secara menyeluruh secara faktual dan akurat sebagaiman adanya.

Sedangkan pendekatan kualitatif menurut David Williams (dalam Usman, dan Purnomo Setiady Akbar, 2008:78) dalam bukunya Motode Penelitian Kualitatif, mengemukakan bahwa pendekatan kualitatif adalah pengumpulan data yang disugukan dalam bentuk informasi pada latar alamiah, dengan menggunakan metode alamiah, dan dilakukan oleh orang atau peneliti yang tertarik secara alamiah.

\section{Fokus Penelitian}

Penelitian ini difokuskan pada faktor-faktor yang menghambat pelaksanaan program ASI eksklusif di Kelurahan Tuladenggi Kecamatan Dungingi Kota Gorontalo, yang dijabarkan pada:

Sosialisasi

Sosialisasi yang dimaksudkan dalam penelitian ini yaitu penyuluhan yang dilakukan oleh petugas Puskesmas tentang akan pentingnya penggunaan ASI eksklusif dan tentang cara-cara yang tepat dalam menyusui serta manfaat akan ASI eksklusif bagi bayi di Kelurahan Tuladenggi Kecamatan Dungingi Kota Gorontalo Pengetahuan

Pengetahuan yang dimaksudkan dalam penelitian ini yaitu wawasan para orang tua (ibu) tentang cara-cara yang tepat dalam menyusui serta manfaat akan ASI eksklusif bagi bayi di Kelurahan Tuladenggi Kecamatan Dungingi Kota Gorontalo 


\section{Pendampingan}

Pendampingan dimaksudkan yang dimaksudkan dalam penelitian ini yaitu upaya pemantauan kader melalui pendekatan langsung guna memastikan penggunaan ASI eksklusif secara tepat dan benar di Kelurahan Tuladenggi Kecamatan Dungingi Kota Gorontalo

\section{HASIL PENELITIAN DAN PEMBAHASAN}

Berikut uraian pembahasan terkait faktor-faktor yang menghambat pelaksanaan program ASI Eksklusif di Kelurahan Tuladenggi Kecamatan Dungingi Kota Gorontalo yang difokuskan pada tiga faktor yakni; sosialisasi, pengetahuan para ibu serta pendampingan.

Tingkat keberhasilan suatu pembangunan kesehatan di sebuah daerah dapat dilihat dari penurunan angka kematian bayi dan peningkatan status gizi masyarakat serta peningkatan kemauan, kesadaran dan kualitas sumber daya manusia guna tercapainya hidup sehat bagi setiap masyarakat agar dapat meningkatkan derajat kesehatan masyarakat yang setinggi-tingginya, maka sudah menjadi kewajiban Negara dan/atau pemerintah sebagai penyelenggara pemerintahan untuk mengupayakan agar hal tersebut dapat terlaksana dengan baik, upaya yang dapat dilakukan yaitu dengan merealisasikan kebijakan yang dibuat guna terpenuhinya hak-hak masyarakat yang telah dijamin oleh undang-undang.

Indonesia saat ini masih menghadapi masalah gizi ganda yaitu kondisi dimana disatu sisi masih banyaknya jumlah penderita gizi kurang, sementara di sisi lain jumlah masyarakat yang mengalami gizi lebih cenderung meningkat. Masalah gizi ganda ini sangat erat kaitannya dengan gaya hidup masyarakat dan perilaku gizi. Status gizi masyarakat akan baik apabila perilaku gizi yang baik dilakukan pada setiap tahap kehidupan termasuk pada bayi.

Salah satu kebijakan yang sedang digalakkan pemerintah saat ini adalah pelaksanaan program Inisiasi Menyusu Dini (IMD) dan ASI eksklusif bagi anak, karena pada dasarnya anak mempunyai peran yang sangat penting yaitu sebagai generasi bangsa maka sudah selayaknya Negara dan/atau pemerintah mempersiapkan segala sesuatu agar generasi bangsa tersebut dapat tumbuh dan berkembang dengan baik.

ASI eksklusif merupakan makanan terbaik bagi anak pada masa awal pertumbuhan, sehingga pemerintah perlu memperhatikan hal ini dengan berupaya menyediakan fasilitas yang layak dan memadai guna mewujudkan terselenggaranya program pemberian ASI eksklusif di sebuah daerah khususnya di Kota Gorontalo dan lebih khusus lagi di Kelurahan Tuladenggi.

Dengan demikian, untuk memenuhi pelaksanaan program ASI eksklusif yang telah diuraikan diatas, pemerintah berupaya melakukan sosialisasi. Dalam penelitian ini, sosialisasi adalah penyuluhan yang dilakukan oleh petugas Puskesmas tentang akan pentingnya penggunaan 
ASI eksklusif dan tentang cara-cara yang tepat dalam menyusui serta manfaat akan ASI eksklusif bagi bayi di Kelurahan Tuladenggi Kecamatan Dungingi Kota Gorontalo.

Berdasarkan hasil penelitian dan analisis, maka dapat ketahui bahwa kegiatan sosialisasi yang dilakukan oleh para petugas belum optimal. Hal ini terlihat dari bentuk sosialisasi yang hanya tersentral pada satu serta persepsi petugas sendiri yang menganggap bahwa masyarakat sudah tahu tentang penggunaan ASI eksklusif sehingga tidak lagi terjun langsung ke tengah-tengah masyarakat.

Pengetahuan ibu tentang cara menyusui yang benar dapat mendukung bayi mendapatkan ASI secara maksimal. Namun di wilayah Kelurahan Tuladenggi, hal itu masih sulit terwujud, dikarenakan pada penelitian ini secara keseluruhan pengetahuan ibu tentang menyusui disimpulkan masih dalam katagori rendah. Kurangnya pengertian dan pengetahuan ibu tentang ASI dan menyusui menyebabkan ibu-ibu akan mudah terpengaruh dan akhirnya beralih menggunakan susu formula.

Pengetahuan ibu yang kurang mengenai posisi menyusui yang benar bisa berdampak ibu sering cepat merasa lelah, puting susu lecet dan nyeri, radang payudara, selain itu bayi juga merasa tidak nyaman. Padahal menurut Pakar Laktasi untuk mendapatkan manfaat optimal dari pemberian ASI diperlukan dua syarat utama. Syarat pertama yaitu pemberian ASI harus dilakukan dengan baik sehingga keberhasilan menyusui dapat dicapai. Syarat kedua, pemberian ASI harus dilakukan secara eksklusif minimal selama empat bulan dan maksimal enam bulan. Lebih lanjut dijelaskan bahwa pemberian ASI yang baik yaitu yang sesuai kebutuhan. Namun pada penelitian ini tidak banyak ibu yang tahu cara mengatasi permasalahan yang terjadi selama menyusui seperti puting datar, puting lecet, radang payudara, dll.

Selain pengetahuan ibu mengenai menyusui yang benar dan tahu bagaimana mengatasi apabila payudara mengalami masalah, pengetahuan tentang menyimpan ASI juga dianggap memegang peranan penting. Kurangnya pengetahuan ibu tentang cara menyimpan ASI berdampak kurangnya asupan ASI bagi bayi yang ibunya bekerja atau berpergian dalam waktu lama.

Dalam penelitian ini yang dimaksud dengan pengetahuan adalah wawasan para orang tua (ibu) tentang cara-cara yang tepat dalam menyusui serta manfaat akan ASI eksklusif bagi bayi di Kelurahan Tuladenggi Kecamatan Dungingi Kota Gorontalo.

Berdasarkan hasil penelitian dan analisis penulis maka dapat diketahui bahwa pengetahuan masyarakat akan penggunaan dan manfaat Air Susu Ibu (ASI) Eksklusif masih rendah. Hal ini terlihat dari pengetahuan para ibu yang kurang tentang teknik dan tata cara menggunakan ASI eksklusif khususnya untuk ASI hasil perasan yang kemudian disterilkan keruang pendingin agar bisa digunakan tanpa harus mengganggu aktivitas kerja para ibu. 
Selain itu, peran kader dalam pelaksanaan program ASI eksklusif cukup vital. Kader melakukan pendampingan dengan memberikan informasi dan dukungan kepada ibu menyusui akan pentingnya penggunaan ASI eksklusif serta proses penyajiannya. Dalam penelitian ini, pendampingan adalah upaya pemantauan kader melalui pendekatan langsung guna memastikan penggunaan ASI eksklusif secara tepat dan benar di Kelurahan Tuladenggi Kecamatan Dungingi Kota Gorontalo.

Berdasarkan hasil penelitian dan analisis penulis maka dapat diketahui bahwa pendampingan pelaksanaan program ASI eksklusif di Kelurahan Tuladenggi belum optimal. Hal ini dikarenakan keterbatasan jumlah kader yang tidak sebanding dengan luasnya wilayah kerja para kader. Selain itu para kader kurang menguasai proses laktasi baik secara teknis maupun secara teoritis.

\section{SIMPULAN}

Berdasarkan hasil penelitian dan pembahasan, maka dapat disimpulkan bahwa:

1. Sosialisasi yang dilakukan oleh para petugas belum optimal. Hal ini terlihat dari bentuk sosialisasi yang hanya tersentral pada satu tempat saja yakni di posyandu atau di Kantor Lurah serta persepsi petugas sendiri yang menganggap bahwa masyarakat sudah tahu tentang penggunaan ASI eksklusif sehingga tidak lagi terjun langsung ke tengah-tengah masyarakat.
2. Pengetahuan masyarakat akan penggunaan dan manfaat ASI eksklusif masih rendah. Hal ini terlihat dari pengetahuan para ibu yang kurang tentang teknik dan tata cara menggunakan ASI eksklusif khususnya untuk ASI hasil perasan yang kemudian disterilkan keruang pendingin agar bisa digunakan tanpa harus mengganggu aktivitas kerja para ibu.

3. Pendampingan pelaksanaan program ASI eksklusif di Kelurahan Tuladenggi belum optimal. Hal ini dikarenakan keterbatasan jumlah kader yang tidak sebanding dengan luasnya wilayah kerja para kader. Selain itu para kader kurang menguasai proses laktasi baik secara teknis maupun secara teoritis.

\section{SARAN}

Berdasarkan kesimpulan di atas, maka disarankan hal-hal berikut:

1. Perlunya dilakukan kegiatan sosialisasi yang lebih komprehensip dengan melakukan kunjungan langsung kerumah-rumah warga.

2. Perlunya meningkatkan pengetahuan para ibu dengan memberikan kelas khusus tentang pentingnya penggunaan ASI eksklusif

3. Perlunya dilakukan pendampingan dengan memberikan pembekalan wawasan dan teknik laktasi kepada para kader 


\section{DAFTAR PUSTAKA}

Abdul Wahab, Solichin. 2008. Analisis Kebijaksaan dari formulasi ke implementasi kebijaksanaan negara. Jakarta: Bumi Aksara

Abidin, I. 2004. Kebijakan Publik, Teori dan Praktek. Yogyakarta: Penerbit Andi.

Albrow. 2010. Birokrasi, (Cetakan Ketiga). Yogyakarta: Tiara Wacana.

Arikunto, $\quad$ Suharsimi. 2009. Manajemen Pendidikan. Yogyakarta: Aditya Media.

Danim, Sudarwan. 2011. Pengantar Studi Penelitian Kebijakan. Jakarta: Bumi Aksara.

Dimock \& Fox, 2007. Administrasi Negara Jilid 1 dan 2. Jakarta: Rieneka Cipta.

Dunn, W. N. 2009. Public Policy Analysis: An Introduction. Englewood Cliffs, N.J: Prentice Hall.

Gie, The Liang 2010. Administrasi Perkantoran. Yokyakarta : Modern Liberty

Guntur, Setiawan.

2010. Implementasi Dalam

Birokrasi Pembangunan.

Bandung: Remaja Rosdakarya.

Hasan Shadily. 2007. Kamus Besar Bahasa Indonesia. Jakarta: Balai Pustaka.

Ibrahim, Amin. 2008. Teori dan Konsep Pelayanan Publik Serta Implementasinya. Bandung: Mandar Maju.

Ismani, 2009. Debirokrasi dan Deregulasi. Jakarta: Obor.
LAN. 2008. Standar Pelayanan Publik. Jakarta: Lembaga Administrasi Negara.

Kadarwati. 2008. Administrasi Negara Pembangunan. Jakarta: Karunia. LP3ES.

Keban, Jeremias T. 2008. Enama dimensi Strategi Administrasi Publik, Konsep, Teori dan Isu. Yogyakarta: Gava Media.

Kurniawan, Luthfi J. Mokhamad Najih. 2008. Paradigma Kebijakan Pelayanan Publik. Malang: Trans Publishing

Kusdi. 2009. Transformasi Pelayanan Publik. Yogyakarta: Pembaruan.

Marzuki. 2012. Metodologi Riset, Yogyakarta: Ekonisia.

Moleong, Jexy J., 2007. Metodologi Penelitian Kualitatif. Bandung: Rosda.

Nurdin, Usman. 2009. Konteks Implementasi Berbasis Kurikulum. Jakarta: PT. Raja Grafindo Persada.

Pasolong, Harbani. 2011. Teori Administrasi Publik. Bandung: Alfabeta.

Rosenbloom, David H, 2008. Public Administration; understanding Management, Politics, and Law in the Public Sector. $6^{\text {th }}$ edition. New York: Mc Graw Hill International Edition.

Santoso, Pandji. 2008. "Administrasi Publik, Teori dan Aplikasi Good Governance”, Cet. Pertama. Bandung: PT. Refika Aditama.

Santoso. 2009. Birokrasi Terhadap Peningkatan Pelayanan Publik 
Di Era Otonomi. Bandung: PT. Refika Aditama.

Sri Yuliani, 2009. Pengantar Ilmu Administrasi Negara. Surakarta: FISIP Universitas Sebelas Maret. Sugiyono. 2013. Prosedur Penelitian: Suatu Pendekatan Praktek, Jakarta: PT. Rineka Cipta.

Sulistiyani Ambar Teguh. 2011. Manajemen dan Sumber Daya Manusia: Konsep Teori dan. Pengembangan Dalam Konteks Organisasi Publik. Yogyakarta: Graha Ilmu.

Tangkilisan, Hersel Nogi S. 2008. Kebijakan Publik yang Membumi. Yogyakarta: YPAPI dan Lukman Offset.

Ulbert Silalahi, 2011. Pengantar Ilmu Administrasi. Bandung: Sinar Baru.

Wibawa, S. 2007. Kebijakan Publik. Jakarta: Intermedia.

Winarno, Budi. 2007. Kebijakan Publik: Teori dan Proses. Yogyakarta: Media Pressindo. 